\title{
Polymorphism in COX-2 modifies the inverse association between Helicobacter pylori seropositivity and esophageal squamous cell carcinoma risk in Taiwan: a case control study
}

\author{
Huang-Ming $\mathrm{Hu}^{1}$, Chao-Hung Kuo ${ }^{1,2,3}$, Chien-Hung Lee ${ }^{4,5}$, I-Chen $\mathrm{Wu}^{2}$, Ka- \\ Wo Lee ${ }^{6,7}$, Jang-Ming Lee ${ }^{8}$, Yih-Gang Goan' ${ }^{9}$, Shah-Hwa Chou'10, Ein- \\ Long $\mathrm{Kao}^{10}$, Ming-Tsang $\mathrm{Wu}^{4,11}$ and Deng-Chyang $\mathrm{Wu}^{* 2,3,4}$
}

Address: ${ }^{1}$ Division of Internal Medicine, Kaohsiung Municipal Hsiao-Kang Hospital, Kaohsiung, Taiwan, ${ }^{2}$ Division of Gastroenterology, Department of Internal Medicine, Kaohsiung Medical University Hospital, Kaohsiung, Taiwan, ${ }^{3}$ Department of Medicine, Faculty of Medicine, College of Medicine, Kaohsiung Medical University, Taiwan, ${ }^{4}$ Center of Excellence for Environmental Medicine, Kaohsiung Medical University, Kaohsiung, Taiwan, ${ }^{5}$ Department of Public Health, Kaohsiung Medical University, Kaohsiung, Taiwan, ${ }^{6}$ Department of Otolaryngology, Kaohsiung Medical University Hospital, Kaohsiung, Taiwan, ${ }^{7}$ Department of Otolaryngology, Faculty of Medicine, College of Medicine, Kaohsiung Medical University, Taiwan, ${ }^{8}$ Department of Surgery, National Taiwan University Hospital, Taipei, Taiwan, ${ }^{9}$ Department of Chest Surgery, Kaohsiung Veterans General Hospital, Kaohsiung, Taiwan, ${ }^{10}$ Department of Chest Surgery, Kaohsiung Medical University Hospital, Kaohsiung, Taiwan and ${ }^{11}$ Department of Family Medicine, Graduate Institute of Occupational Safety and Health, Kaohsiung Medical University, Kaohsiung, Taiwan

Email: Huang-Ming Hu - huhuangming@ms66.url.com.tw; Chao-Hung Kuo - kjh88@seed.net.tw; Chien-Hung Lee - cnhung@kmu.edu.tw; IChen Wu - minicawu@yahoo.com.tw; Ka-Wo Lee - kawolee@kmu.edu.tw; Jang-Ming Lee - jangming@ha.mc.ntu.edu.tw; Yih-

Gang Goan -goan@ksts.seed.net.tw; Shah-Hwa Chou-0740099@kmhk.kmu.edu.tw; Ein-Long Kao - kaeil@cc.kmu.edu.tw; MingTsangWu - e_encourage@yahoo.com; Deng-Chyang Wu* - dechwu@yahoo.com

* Corresponding author

Published: 23 May 2009

BMC Gastroenterology 2009, 9:37 doi:10.1 I86/I47|-230X-9-37
Received: 7 November 2008

Accepted: 23 May 2009

This article is available from: http://www.biomedcentral.com/I47I-230X/9/37

(c) 2009 Hu et al; licensee BioMed Central Ltd.

This is an Open Access article distributed under the terms of the Creative Commons Attribution License (http://creativecommons.org/licenses/by/2.0), which permits unrestricted use, distribution, and reproduction in any medium, provided the original work is properly cited.

\begin{abstract}
Background: Overexpression of Cyclooxygenase-2 (COX-2) was observed in many types of cancers, including esophageal squamous cell carcinoma (ESCC). One functional SNP, COX-2 I 195G/A, has been reported to mediate susceptibility of ESCC in Chinese populations. In our previous study, the presence of Helicobacter pylori $(H$. pylori) was found to play a protective role in development of ESCC. The interaction of COX-2 and $\mathrm{H}$. pylori in gastric cancer was well investigated. However, literature on their interaction in ESCC risk is scarce. The purpose of this study was to evaluate the association and interaction between COX-2 single nucleotide polymorphism (SNP), H. pylori infection and the risk of developing ESCC.

Methods: One hundred and eighty patients with ESCC and 194 controls were enrolled in this study. Personal data regarding related risk factors, including alcohol consumption, smoking habits and betel quid chewing, were collected via questionnaire. Genotypes of the COX-2 - II95 polymorphism were determined by PCR-based restriction fragment length polymorphism. $\mathrm{H}$. pylori seropositivity was defined by immunochromatographic screening test. Data was analyzed by chisquared tests and polytomous logistics regression.

Results: In analysis adjusting for the covariates and confounders, $H$. pylori seropositivity was found to be inversely association with the ESCC development (adjusted OR: $0.5,95 \% \mathrm{Cl}: 0.3-0.9$ ). COX2 - II 95 AA homozygous was associated with an increased risk of contracting ESCC in comparison
\end{abstract}


with the non-AA group, especially among patients with $H$. pylori seronegative (adjusted OR ratio: 2.9, 95\% Cl: 1.2 - 7.3). The effect was strengthened among patients with lower third ESCC (adjusted OR ratio: 6.9, 95\% Cl 2.I - 22.5). Besides, $H$. pylori seropositivity conveyed a notably inverse effect among patients with COX-2 AA polymorphism (AOR ratio: $0.3,95 \% \mathrm{Cl}: 0.1$ - 0.9), and the effect was observed to be enhanced for the lower third ESCC patients (AOR ratio: 0.09, $95 \% \mathrm{Cl}: 0.02-0.47, p$ for multiplicative interaction 0.008 )

Conclusion: $H$. pylori seropositivity is inversely associated with the risk of ESCC in Taiwan, and COX-2 - II95 polymorphism plays a role in modifying the influence between $H$. pylori and ESCC, especially in lower third esophagus.

\section{Background}

Esophageal cancer occurs worldwide with a variable geographic distribution[1] and the incidence is high in certain parts of China [2,3]. This malignancy has two histological subtypes: squamous cell carcinoma (ESCC) and adenocarcinoma. Most of the esophageal cancers are ESCC, although the incidence of the adenocarcinoma is increasing in West countries [4,5]. ESCC is one of the most fatal forms of carcinoma. Because of dissatisfying the improvements in prognosis, primary prevention and intervention are important in the control of the disease. The development of ESCC of the esophagus is a multifactor process associated with a variety of risk factors. Several environmental factors have been implicated in the pathogenesis of ESCC, including tobacco smoking, and alcohol drinking [6-9]. Recent research in Taiwan also mentioned that betel quid chewing was another important factor in developing ESCC $[10,11]$. However, some cases still developed ESCC without such risk factors, indicating that there are other risk factors associated with developing ESCC.

Overexpression of Cyclooxygenase (COX)-2 is observed in many types of cancers, including ESCC [12-14]. COX-2 is the inducible form of the enzyme for prostanoid synthesis, and the active products, such as prostaglandins and prostacyclin, have been implicated in carcinogenesis $[15,16]$. COX-2 is also involved in many processes fundamental to tumor development, such as apoptosis, cell adhesion, proliferation, invasion, metastasis and angiogenesis [17-19]. The COX-2 expression can be induced by variable stimuli, including cytokines and growth factors. But it is believed that transcription regulation is the major process in regulating the express of COX-2. Several naturally occurring single nucleotide polymorphism (SNP) in the COX-2 promoter region were observed and its distribution varied in different ethnics. One functional SNP, COX-2 -1195G/A, has been reported in Chinese populations previously and it locates in the core recognition sequence of c-MYB in the promoter region [20]. c-MYB is one of the nuclear proteins and it may have the ability to induce the transcription of COX-2 gene [20,21], and then to inhibit apoptosis by overexpression of COX-2 $[17,21]$.
The SNP on c-MYB-recognized region can influence the expression of COX-2 and may play a role in mediating susceptibility of ESCC [20].

The role of $H$. pylori in development of ESCC is still puzzling. Several studies revealed the positive correlation between $H$. pylori infection and ESCC by histological pattern. An investigation from a Swedish population disclosed a positive association between ESCC and both $H$. pylori Cag-A positive infection and atrophic gastritis[22]. Bahmanyar et al [23] provided another finding that gastric ulcer patients had an $80 \%$ increased risk of ESCC, and supposed that corpus atrophy may play a role in ESCC etiology. On the contrary, H. pylori infection had also been mentioned to be associated with a decreased risk of developing ESCC [24,25]. According to the study from Wu et al [25], the protective effect of $H$. pylori infection was stronger in younger subjects, nonsmokers, nondrinkers and in the lower third cases of ESCC. This finding provides a clue that the influence of $H$. pylori infection in developing ESCC may vary according to the location in the esophagus.

Both overexpression of COX-2 and $H$. pylori infection were associated with the development of gastric adenocarcinoma [26-28]. The presence of $H$. pylori has also played a role in induction of expression of COX-2 in stomach [29-31]. However, the interaction of $H$. pylori and COX-2 in risk of ESCC has not been well investigated. In the present study, we conducted an incident case-control study to evaluate the relationship of SNP in the COX-2 promoter, $H$. pylori infection, and their interaction in the risk of developing ESCC.

\section{Methods \\ Participants}

All subjects were consecutively recruited at the Kaohsiung Medical University Hospital. This study was carried out according to the principles of the Declaration of Helsinki and was approved by the Institutional Review Board (IRB) of Kaohsiung Medical University Hospital (KMUH-IRB960114). One hundred and eighty patients of ESCC and 194 controls were enrolled in this study. All patients of 
ESCC were histopathologically confirmed using gastroscopic biopsies. Their data were collected within one month after diagnosis, at the time when they admitted to hospital for staging or treatment. The controls were healthy and cancer-free individuals collected during the same period from the group receiving routine health examination, including gastroscopy at the same hospital. They were selected according the frequency matched to the patients based on age, sex and ethnicity. The exclusion criteria of both groups included previous cancer history, previous peptic ulcer history, previous $H$. pylori eradication history, and blood transfusion within 6 months.

Informed consent was obtained from each subject, and personal data regarding demographic characteristics such as sex, age and related risk factors, including alcohol consumption, smoking habits and betel quid chewing, were collected via questionnaire from each participant after interviewing with trained interviewer. Alcoholic drinker was defined if the subject had drunk wine, beer or distilled spirits more than once per week for at least 6 months. Those who had smoked more than 10 cigarettes per week for at least 6 months were defined as cigarette smokers. Those who chewed betel quid each week for at least the same period were defined as betel quid chewers, and we defined 10 betel quids as one pack.

\section{Location of ESCC}

Location of the ESCC was identified by endoscopic finding or by the image of the chest computed tomography if the esophageal lumen containing ESCC was narrowing. Lesions were classified according to their location in upper, middle or lower third esophagus [32]. Upper third esophagus extended from cricopharnygeal sphincter (15 $\mathrm{cm})$ to the tracheal bifurcation $(23 \mathrm{~cm})$. Lower third esophagus extended from the approximate level of T9 vertebral body $(32 \mathrm{~cm})$ to the gastroesophageal junction (40 $\mathrm{cm}$ ). If the lesion involved more than one region, location was defined according the high percentage of mass located.

\section{COX-2 - I I95 polymorphism detection}

Peripheral blood samples were collected from all patients and controls. Heparinized whole blood was centrifuged at 2,000 rpm for $10 \mathrm{~min}$ to isolate plasma supernatant (for H. pylori detection, described as below). Genomic DNA was extracted from remained blood cells using standard phenol-chloroform method. Genotypes of the COX-2 promoter region containing $-1195 \mathrm{G} \rightarrow$ A were determined by PCR-based restriction fragment length polymorphism (PCR-RFLP). The PCR primer pairs used to amplify the COX-2 promoter region were 5'-CCC TGA GCA CTA CCC ATG AT-3' (forward) and 5'-GCC CTT CAT AGG AGA TAC TGG-3' (reverse). PCR was performed at a $25 \mu \mathrm{L}$ reaction mixture containing $1.5 \mu \mathrm{l}$ of DNA tem- plate, 1 unit of Taq DNA polymerase (Promega, Madison, $\mathrm{WI}), 0.1 \mu \mathrm{mol} / \mathrm{L}$ of each primer, $0.2 \mathrm{mmol} / \mathrm{L}$ of deoxynucleoside triphosphate, $1.5 \mathrm{mmol} / \mathrm{L}$ of $\mathrm{MgCl}_{2}$, and $1 \times$ reaction buffer. The PCR profile included an initial melting step of 2 minutes at $95^{\circ} \mathrm{C}$, followed by 35 cycles of $30 \mathrm{sec}$ onds at $95^{\circ} \mathrm{C}, 30$ seconds at $60^{\circ} \mathrm{C}, 45$ seconds at $72^{\circ} \mathrm{C}$, and a final elongation step of 5 minutes at $72^{\circ} \mathrm{C}$. Restriction enzymes PvuII (New England Biolabs, Beverly, MA) was used to distinguish -1195G $\rightarrow$ A genotype. Genotyping was performed without knowledge of the case or control status of the subjects.

\section{H. pylori detection}

Because of the variable stenotic change of esophagus in ESCC subjects, we could not well evaluate the H. pylori infection status by sampling from gastric tissue. So $H$. pylori seropositivity was defined according to the existence of IgG antibody in plasma. The isolated plasma was stored at $-70^{\circ} \mathrm{C}$ until analyzed. A commercial immunochromatographic screening test (Chimbio H. pylori STAT-PAK, Chimbio Diagnostic System, Inc., Medford NY) was used to detect $H$. pylori antibodies in plasma. The results were read 10 minutes by two research technicians after the subject's plasma was placed into the sample well. In accordance with the manufacturer's instructions, the sensitivity and specificity of the immunochromatographic test were $94 \%$ and $98 \%$ respectively.

\section{Statistic analysis}

Univariate analysis was performed with the chi-squared tests in order to search for associations between demographic characteristics and ESCC. The Hardy-Weinberg equilibrium test was used to assess the discrepancies between the observed and the expected COX-2 1195G $\rightarrow$ A genotype frequencies among control subjects. Because of two subgroups of ESCC cases were defined (upper two third and lower third), polytomous logistics regression was applied in the multivariate analysis to determine the risk of contracting the two defined cancer groups $[33,34]$. Estimates were adjusted for covariates and confounders, including age, gender, educational level and consumption of tobacco, alcohol and betel quid, in the regression models. The potential interaction between COX-2 1195G $\rightarrow$ A genotype and $H$. pylori seropositivity in the development of ESCC was evaluated by fitting a multiplicative model with cross-product terms representing the interaction. Two-sided P-values of 0.05 or below were considered statistically significant. All analyses were conducted using the statistical packages of Stata[35].

\section{Results}

The demographic characteristics and substance use in both ESCC patients and controls were listed in Table 1. The majority of ESCC patients were male. Substantial differences in the distribution with regard to education level, 
Table I: Distributions and odds ratios of ESCC associated with selected demographic characteristics and substance uses

\begin{tabular}{|c|c|c|c|}
\hline \multirow[t]{2}{*}{ Factor/Category } & Cases & Controls & \multirow[b]{2}{*}{ AOR' $(95 \% \mathrm{Cl})$} \\
\hline & No. (\%) & No. (\%) & \\
\hline Total No. & 180 & 194 & \\
\hline \multicolumn{4}{|c|}{ Anatomic subsite of the esophagus } \\
\hline Upper I/3 & $39(22)$ & & \\
\hline Middle I/3 & $83(46)$ & & \\
\hline Lower I/3 & $58(32)$ & & \\
\hline \multicolumn{4}{|l|}{ Age (years) } \\
\hline$<50$ & $63(35)$ & $70(36)$ & 1.0 \\
\hline $5 I-60$ & $36(20)$ & $58(30)$ & $0.7(0.4-1.2)$ \\
\hline $61-70$ & $45(25)$ & $36(18)$ & $1.4(0.8-2.4)$ \\
\hline$>70$ & $36(20)$ & $30(16)$ & $1.3(0.7-2.4)$ \\
\hline \multicolumn{4}{|l|}{ Gender } \\
\hline Female & $5(3)$ & $7(4)$ & 1.0 \\
\hline Male & $175(97)$ & $187(96)$ & I.3 $(0.4-4.2)$ \\
\hline \multicolumn{4}{|l|}{ Ethnicity } \\
\hline Fukienese & $138(77)$ & $152(78)$ & 1.0 \\
\hline Aborigines & $31(17)$ & $28(15)$ & $1.2(0.7-2.1)$ \\
\hline Others & $11(6)$ & $14(7)$ & $0.9(0.4-2.0)$ \\
\hline \multicolumn{4}{|c|}{ Education level (years) } \\
\hline$<7$ & $94(52)$ & $51(26)$ & 1.0 \\
\hline $7-12$ & $77(43)$ & $86(44)$ & $0.7(0.4-1.4)$ \\
\hline$>12$ & $9(5)$ & $57(30)$ & $0.2(0.1-0.6)$ \\
\hline$p$ for trend & & & 0.001 \\
\hline \multicolumn{4}{|c|}{ Tobacco smoking (pack-years)² } \\
\hline No & $14(8)$ & 101 (52) & 1.0 \\
\hline $\mathrm{I}-20$ & $37(20)$ & $26(13)$ & $8.7(3.2-23.6)$ \\
\hline$>20$ & $129(72)$ & $67(35)$ & $7.7(3.4-17.7)$ \\
\hline$p$ for trend & & & $<0.001$ \\
\hline \multicolumn{4}{|c|}{ Alcohol drinking (drink-years)² } \\
\hline No & $36(20)$ & $130(67)$ & 1.0 \\
\hline $1-40$ & $44(24)$ & $34(18)$ & $3.0(1.4-6.4)$ \\
\hline$>40$ & $100(56)$ & $30(15)$ & $7.2(3.6-14.7)$ \\
\hline$p$ for trend & & & $<0.001$ \\
\hline \multicolumn{4}{|c|}{ Betel quid chewing (pack-years) ${ }^{2}$} \\
\hline No & $82(46)$ & $175(90)$ & 1.0 \\
\hline $\mathrm{I}-20$ & $26(15)$ & $7(4)$ & $3.9(1.4-10.8)$ \\
\hline$>20$ & $69(39)$ & $12(6)$ & $5.6(2.5-12.5)$ \\
\hline$p$ for trend & & & $<0.001$ \\
\hline
\end{tabular}

I Odds ratios were adjusted for covariates in the table.

2One drink corresponds to 15.75 -g of alcohol; one smoked pack and chewed pack correspond to 20-cigarettes and I0-betel quids, respectively.

tobacco smoking, alcohol drinking and betel quid chewing were found between ESCC and controls. After adjusting for covariates, high education level ( $>12$ years) had a significantly reduced risk (adjusted odds ratio (AOR): 0.2 , 95\% CI: 0.1 - 0.6) of developing ESCC. On the contrary, tobacco smoking, alcohol drinking and betel quid chewing were associated with an increased risk of ESCC development, with a clear dose-dependent effect in the latter two substances.

The protective effect of $H$. pylori infection on ESCC was assessed in Table 2. Sixty two of 180 (37\%) ESCC patients and 102 of 194 (53\%) controls were H. pylori seropositive. After controlling for the covariates, H. pylori seropositivity was found to confer a 0.5 -fold risk (95\% CI: $0.3-0.9)$ of developing ESCC. To further evaluate the effect of $H$. pylori infection on the ESCC location, ESCC cases were classified as two subgroups: lower third and upper two thirds. Compared with the controls (53\%), the lower third (34\%) and upper two thirds (38\%) of ESCC patients had a lower positive response for $H$. pylori, showing a possible protective effect in the risk of developing ESCC.

The distribution of COX-2 -1195 polymorphism both for the cases and controls was shown in Table 3 . The allelic frequency for $-1195 \mathrm{G}$ was 0.52 in controls and 0.44 in ESCC patients. The polymorphic distribution for COX-2 1195 gene was found to well comply with the Hardy- 
Table 2: Adjusted OR for cancers at upper, middle and lower third of the esophagus associated with seropositivity of $H$. pylori

\begin{tabular}{|c|c|c|c|c|c|c|c|}
\hline \multirow[t]{3}{*}{ H. pylori infection } & \multirow{3}{*}{$\begin{array}{c}\text { Controls } \\
\begin{array}{c}\text { No. } \\
(\%)\end{array}\end{array}$} & \multicolumn{4}{|c|}{ Location of ESCC } & \multicolumn{2}{|c|}{ Total cases } \\
\hline & & \multicolumn{2}{|c|}{ Upper + Middle } & \multicolumn{2}{|r|}{ lower } & \multirow[b]{2}{*}{$\begin{array}{l}\text { No. } \\
(\%)\end{array}$} & \multirow[b]{2}{*}{$\begin{array}{c}\text { AOR' } \\
(95 \% \mathrm{Cl})\end{array}$} \\
\hline & & $\begin{array}{l}\text { No. } \\
(\%)\end{array}$ & $\begin{array}{c}\text { AOR' } \\
(95 \% \mathrm{Cl})\end{array}$ & $\begin{array}{l}\text { No. } \\
\text { (\%) }\end{array}$ & $\begin{array}{c}\text { AOR' } \\
(95 \% \mathrm{Cl})\end{array}$ & & \\
\hline Negative & $\begin{array}{c}92 \\
(47)\end{array}$ & $\begin{array}{c}76 \\
(62)\end{array}$ & 1.0 & $\begin{array}{c}38 \\
(66)\end{array}$ & 1.0 & $\begin{array}{l}114 \\
(63)\end{array}$ & 1.0 \\
\hline Positive & $\begin{array}{l}102 \\
(53)\end{array}$ & $\begin{array}{l}46 \\
(38)\end{array}$ & $\begin{array}{c}0.6 \\
(0.3-1.1)\end{array}$ & $\begin{array}{l}20 \\
(34)\end{array}$ & $\begin{array}{c}0.5 \\
(0.2-1.0)\end{array}$ & $\begin{array}{l}66 \\
(37)\end{array}$ & $\begin{array}{c}0.5 \\
(0.3-0.9)\end{array}$ \\
\hline
\end{tabular}

I Odds ratios were adjusted for the covariates (age, gender, education level, pack-years of cigarette smoking and of betel quid chewing, and drinkyears of alcohol drinking) listed in Table $I$.

Weinberg equilibrium among the controls $(\mathrm{P}>0.05)$. Multivariate polytomous logistic regression analyses showed that COX-2 -1195AA homozygous was associated with an increased risk of contracting ESCC (AOR: 2.3, 95\% CI: 1.0 - 5.2). Compared with the non-AA subgroup, a 2.5 -fold significantly elevated risk (95\% CI: $1.0-6.1$ ) was identified for lower third ESCC patients who carried the AA homozygote.

To understand the influence of COX-2 polymorphism on the ESCC risk with regard to the status of $H$. pylori infection, we presented effect modification stratification analysis in Table 4. Among H. pylori seropositive patients, no significant relationship between COX-2 -1195 genotypes and ESCC was detected. However, among H. pylori seronegative subjects, -1195AA homozygous was found to confer an increased risk in developing ESCC in comparison with non-AA polymorphisms (AOR ratio: 2.9, 95\% CI: 1.2 - 7.3). This effect was strengthened among patients with lower third ESCC (AOR ratio: 6.9, 95\% CI: 2.1 - 22.5). Alternatively, $H$. pylori seropositivity conveyed a notably inverse effect among patients with COX-2 AA polymorphism (AOR ratio: 0.3, 95\% CI: $0.1-0.9$ ). Similarly, such opposite effect was observed to be enhanced for the lower third ESCC patients (AOR ratio: 0.09, 95\% CI: 0.02 0.47). Compared with that for COX-2 non-AA carriers (AOR ratio 1.0), significantly heterogeneous inverse cancer risk for AA carriers was identified at this subsite of ESCC ( $p$ for multiplicative interaction 0.008 ), though limited study samples were used to assess the effect.

\section{Discussion}

Several studies have suggested the association between overexpression of COX-2 and ESCC [12-14]. According the previous study, COX-2 -1195G/A polymorphism, a functional SNP disclosed in Chinese populations, could modified not only COX-2 mRNA level, but the risk of ESCC[20]. In the present study, we found similar result that COX-2 -

Table 3: Adjusted OR for cancers at upper, middle and lower third of the esophagus associated with COX-2 -I I95G/A polymorphism.

\begin{tabular}{|c|c|c|c|c|c|c|c|}
\hline \multirow[t]{3}{*}{ COX-2 polymorphism } & \multirow{3}{*}{$\begin{array}{c}\text { Controls } \\
\begin{array}{c}\text { No. } \\
(\%)\end{array}\end{array}$} & \multicolumn{4}{|c|}{ Location of ESCC } & \multicolumn{2}{|c|}{ Total cases } \\
\hline & & \multicolumn{2}{|c|}{ Upper + Middle } & \multicolumn{2}{|r|}{ Lower } & \multirow[b]{2}{*}{$\begin{array}{l}\text { No. } \\
\text { (\%). }\end{array}$} & \multirow[b]{2}{*}{$\begin{array}{c}\text { AOR' } \\
(95 \% \mathrm{Cl})\end{array}$} \\
\hline & & $\begin{array}{l}\text { No. } \\
\text { (\%). }\end{array}$ & $\begin{array}{c}\text { AORI } \\
(95 \% \mathrm{Cl})\end{array}$ & $\begin{array}{l}\text { No. } \\
\text { (\%). }\end{array}$ & $\begin{array}{c}\text { AORI } \\
(95 \% \mathrm{Cl})\end{array}$ & & \\
\hline GG & $\begin{array}{l}50 \\
(26)\end{array}$ & $\begin{array}{c}23 \\
(19)\end{array}$ & 1.0 & $\begin{array}{c}16 \\
(28)\end{array}$ & 1.0 & $\begin{array}{c}39 \\
(22)\end{array}$ & 1.0 \\
\hline AG & $\begin{array}{l}103 \\
(53)\end{array}$ & $\begin{array}{c}59 \\
(48)\end{array}$ & $\begin{array}{c}1.7 \\
(0.7-4.0)\end{array}$ & $\begin{array}{c}21 \\
(36)\end{array}$ & $\begin{array}{c}0.9 \\
(0.3-2.3)\end{array}$ & $\begin{array}{c}80 \\
(44)\end{array}$ & $\begin{array}{c}1.2 \\
(0.6-2.4)\end{array}$ \\
\hline AA & $\begin{array}{c}4 \mathrm{I} \\
(2 \mathrm{I})\end{array}$ & $\begin{array}{c}40 \\
(33)\end{array}$ & $\begin{array}{c}2.0 \\
(0.7-5.2)\end{array}$ & $\begin{array}{c}21 \\
(36)\end{array}$ & $\begin{array}{c}2.3 \\
(0.8-6.7)\end{array}$ & $\begin{array}{c}61 \\
(34)\end{array}$ & $\begin{array}{c}2.3 \\
(1.0-5.2)\end{array}$ \\
\hline$p$ for $\mathrm{H}-\mathrm{W}^{2}$ & 0.471 & & & & & & \\
\hline $\mathrm{GG}+\mathrm{AG}$ & $\begin{array}{l}153 \\
(79)\end{array}$ & $\begin{array}{c}82 \\
(67)\end{array}$ & 1.0 & $\begin{array}{c}37 \\
(64)\end{array}$ & 1.0 & $\begin{array}{l}119 \\
(66)\end{array}$ & 1.0 \\
\hline AA & $\begin{array}{c}41 \\
(2 I)\end{array}$ & $\begin{array}{c}40 \\
(33)\end{array}$ & $\begin{array}{c}1.4 \\
(0.7-2.9)\end{array}$ & $\begin{array}{c}21 \\
(36)\end{array}$ & $\begin{array}{c}2.5 \\
(1.0-6.1)\end{array}$ & $\begin{array}{c}61 \\
(34)\end{array}$ & $\begin{array}{c}2.0 \\
(1.1-3.9)\end{array}$ \\
\hline
\end{tabular}

I Odds ratios were adjusted for the covariates (age, gender, education level, pack-years of cigarette smoking and of betel quid chewing, and drinkyears of alcohol drinking) listed in Table $\mathrm{I}$.

${ }^{2} p$ value for Hardy-Weinberg equilibrium test. 
Table 4: The effect modification between COX-2 - I 195G/A polymorphism and seropositivity of $H$. pylori on the risk of ESCC at lower third of the esophagus and all cancers

\begin{tabular}{|c|c|c|c|c|c|c|c|c|c|c|}
\hline \multirow{3}{*}{$\begin{array}{l}\text { COX-2 } \\
\text { polymorph } \\
\text { ism }\end{array}$} & \multicolumn{5}{|c|}{ Lower third ESCC cases } & \multicolumn{5}{|c|}{ Total ESCC cases } \\
\hline & \multicolumn{2}{|c|}{ H. pylori-negative } & \multicolumn{2}{|c|}{ H. pylori-positive } & \multirow{2}{*}{$\begin{array}{l}\text { H. pylori } \\
(+) \text { vs. }(-) \\
\text { OR ratio } \\
(95 \% \mathrm{Cl})\end{array}$} & \multicolumn{2}{|c|}{ H. pylori-negative } & \multicolumn{2}{|c|}{ H. pylori-positive } & \multirow{2}{*}{$\begin{array}{l}\text { H. pylori } \\
(+) \text { vs. }(-) \\
\text { OR ratio } \\
(95 \% \mathrm{Cl})\end{array}$} \\
\hline & $\begin{array}{l}\text { Cases/ } \\
\text { Controls }\end{array}$ & $\begin{array}{c}\text { AOR' }^{\prime}(95 \% \\
C l)\end{array}$ & $\begin{array}{l}\text { Cases/ } \\
\text { Controls }\end{array}$ & $\begin{array}{c}\text { AORI } \\
(95 \% \mathrm{Cl})\end{array}$ & & $\begin{array}{l}\text { Cases/ } \\
\text { Controls }\end{array}$ & $\begin{array}{c}\text { AOR' } \\
(95 \% \mathrm{Cl})\end{array}$ & $\begin{array}{l}\text { Cases/ } \\
\text { Controls }\end{array}$ & $\begin{array}{c}\text { AORI } \\
(95 \% \mathrm{Cl})\end{array}$ & \\
\hline$G G+A G$ & $20 / 72$ & 1.0 & $|7 / 8|$ & $\begin{array}{c}1.0 \\
(0.4-2.5)\end{array}$ & $\begin{array}{c}1.0 \\
(0.4-2.5)\end{array}$ & $73 / 72$ & 1.0 & $46 / 81$ & $\begin{array}{c}0.7 \\
(0.4-1.4)\end{array}$ & $\begin{array}{c}0.7 \\
(0.4-1.4)\end{array}$ \\
\hline AA & $18 / 20$ & $\begin{array}{c}6.9 \\
(2.1-22.5)\end{array}$ & $3 / 21$ & $\begin{array}{c}0.6 \\
(0.1-2.8)\end{array}$ & $\begin{array}{c}0.09 \\
(0.02- \\
0.47)\end{array}$ & $4 I / 20$ & $\begin{array}{c}2.9 \\
(1.2-7.3)\end{array}$ & $20 / 21$ & $\begin{array}{c}0.9 \\
(0.4-2.1)\end{array}$ & $\begin{array}{c}0.3 \\
(0.1-0.9)\end{array}$ \\
\hline $\begin{array}{l}\text { AA vs. } \\
\text { GG+AG } \\
\text { OR ratio } \\
(95 \% \mathrm{Cl})\end{array}$ & & $\begin{array}{c}6.9 \\
(2.1-22.5)\end{array}$ & & $\begin{array}{c}0.6 \\
(0.1-2.7)\end{array}$ & & & $\begin{array}{c}2.9 \\
(1.2-7.3)\end{array}$ & & $\begin{array}{c}1.2 \\
(0.5 \text { to } 3.0)\end{array}$ & \\
\hline $\begin{array}{l}p \text { for } \\
\text { interaction } \\
2\end{array}$ & & & & 0.008 & & & & & 0.172 & \\
\hline
\end{tabular}

I Odds ratios were adjusted for the covariates (age, gender, education level, pack-years of cigarette smoking and of betel quid chewing, and drinkyears of alcohol drinking) listed in Table I.

2Interaction was examined with likelihood ratio test for cross-product terms based on a multiplicative model.

1195AA homozygous, which had higher COX-2 mRNA level, was related to increased risk of ESCC (AOR: 2.0, 95\% CI: 1.1 - 3.9) compared with non-AA genotype subjects in multivariate logistic regression analysis. The trend was the same in the lower third ESCC cases (AOR: 2.5, 95\% CI: 1.0 - 6.1). However, the relationship was absent in upper two third esophageal area. This is consistent with the existing evidences from Kawabe et al [36] and Sivula et al [37], which mentioned that high COX-2 expression in ESCC was found significantly more often in lower parts of the esophagus. These results suggest that the increased risk of ESCC in the lower third part of the esophagus may be associated with the COX-2 -1195AA homozygous, which induces higher COX-2 expression.

In our previous study as Wu et al [25], we mentioned that subjects with positive $H$. pylori infection had reduced risk of developing ESCC. In the present study with newly collected ESCC subjects and controls, we also found the same effect of $H$. pylori in ESCC. On the contrary, there are different findings. Bahmanyar et al[23] found that patients with gastric ulcer history had higher risk of developing ESCC, with supposed positive H. pylori infection status and corpus atrophy change via ulcer presentation. We did not evaluate the association between gastric ulcer and ESCC because a higher proportion of gastric ulcer was induced by drugs in Taiwan [38], especially in elderly subjects who were also the high risk group of ESCC by age.
The COX-2 expression induced by H. pylori infection has been well evaluated in gastric mucosa previously $[29,39]$, but research about the interaction in esophageal squamous cells is scarce. A study concerning the histological change of low esophageal mucosa before and after $H$. pylori eradication disclosed that COX-2 expression gradually increased after treatment [40]. This observation suggests that COX-2 expression in low esophageal region is lower under $H$. pylori seropositive status. In the present study, we put the COX-2 -1195G/A polymorphism under consideration and found that COX-2 -1195AA homozygote in $H$ pylori seronegative status had increased ESCC risk (AOR ratio: 2.9, 95\% CI: 1.2 - 7.3). This effect was strengthened among subjects with lower third ESCC (AOR ratio: 6.9, 95\% CI 2.1 - 22.5). Furthermore, $H$. pylori seropositivity conveyed a notably inverse effect in ESCC risk (AOR ratio: 0.3, 95\% CI: $0.1-0.9$ ) in subjects carrying COX-2 AA genotype. Such opposite effect was observed to be enhanced for the lower third ESCC patients (AOR ratio: 0.09, 95\% CI: $0.02-0.47$ ). However, such relationship between $H$. pylori infection and the risk of ESCC did not persist in COX-2 non-AA genotype. These findings suggest that the protective effect to lower third ESCC risk provided by $H$. pylori seropositivity may be mediated by influencing COX-2 AA genotype expression. Our data also indicated the area in which to search for underlying mechanism. 
In consideration of the lower third part of the esophagus, one of the possible changes under chronic $H$. pylori infection is the reduced load of esophageal acid. Long-term $H$. pylori infection may provoke gastric atrophy, accompany with hypochlorhydria [41-44], and the prevalence increased with advancing age [45]. According to the study from Lurje et al [46], COX-2 mRNA expression is significantly increased in acid-exposed compared to nonexposed squamous epithelium. Another study from Vallbohmer et al [47] disclosed that COX-2 gene expression was increased in the distal esophageal squamous mucosa of most patients with gastro-esophageal reflux disease, and the increased COX-2 expression was usually normalized following anti-reflux surgery. These findings provide a clue that ESCC development in the lower part of the esophagus may have a similar carcinogenesis pathway as esophageal adenocarcinoma in consideration of acid exposure risk. However, further studies are needed to evaluate the relationship between acid exposure in squamous cell epithelium and development of ESCC.

There are some limitations to the present study. Firstly, we selected controls only from the group receiving health examination in which gastroscopy was included. Selection bias resulting from the will of receiving invasive gastroscopy might have distorted our findings. However, the distribution of COX-2 -1195 genotypes in controls still complies the Hardy-Weinberg equilibrium. In addition, the H. pylori infection status was determined according to the result of serologic method. The ESCC location was determined relying on the image of chest computed tomography in part of ESCC cases. Misclassification happened in these variables might influence our study results. Furthermore, limited studied samples might lead to a relatively lower statistical power in certain subgroups. On the other hand, the strength of our study is that previous studies $[11,34,48]$ for the relationship between habitual substance use and the risk of ESCC from the same area of Taiwan provide us adequate information to well design the questionnaire and to adjust the influence from those potential confounding factors.

\section{Conclusion}

This study provided evidence that both COX-2 -1195G/A polymorphism and $H$. pylori infection had influence in risk of ESCC in Taiwanese population. Subjects carrying COX-2 -1195 AA homozygote has increased risk of ESCC in lower third esophagus. The H. pylori seropositivity had an inverse association in ESCC development, and it was observed to be enhanced in subgroup of COX-2 -1195AA genotype, especially when ESCC is located in lower third esophagus. These findings suggest that COX-2 -1195 polymorphism plays a role in modifying the inverse association between $H$. pylori infection and risk of ESCC. The underlying mechanism needs further investigation.

\section{Abbreviations}

ESCC: esophageal squamous cell carcinoma; COX-2: cyclooxygenase 2; SNP: single nucleotide polymorphism; H. pylori: helicobacter pylori; PCR: polymerase chain reaction; RFLP: restriction fragment length polymorphism; AOR: adjusted odds ratio; CI: confidence interval.

\section{Competing interests}

The authors declare that they have no competing interests.

\section{Authors' contributions}

HMH participated in the design of the study, carried out the genetic analysis and drafted the manuscript. CHK performed literature review and administered to the direction of discussion section. CHL and MTW participated in the design of the questionnaire and performed the statistic analysis. ICW carried out the immunochromatographic test and participated in collections of clinical data. JML and YGG participated in study design. KWL, SHC and ELK assisted in the collection of clinical data. DCW participated in its design and coordination, and supervised the study. All authors read and approved the final manuscript.

\section{Acknowledgements}

This research was supported by grants from the Kaohsiung Medical University Hospital (KMUH96-6G0I), Kaohsiung Municipal Hsiao-Kang Hospital (KMHK-96-0I2), and Center of Excellence for Environmental Medicine, Kaohsiung Medical University.

\section{References}

I. Parkin DM, Bray F, Ferlay J, Pisani P: Global cancer statistics, 2002. CA Cancer J Clin 2005, 55(2):74- 108.

2. Yang CS: Research on esophageal cancer in China: a review. Cancer Res 1980, 40(8 Pt I):2633-2644.

3. Qiao YL, Hou J, Yang L, He YT, Liu YY, Li LD, Li SS, Lian SY, Dong $\mathrm{ZW}$ : The trends and preventive strategies of esophageal cancer in high-risk areas of Taihang Mountains, China. Zhongguo Yi Xue Ke Xue Yuan Xue Bao 200I, 23(1): I0-14.

4. Blot WJ, Devesa SS, Kneller RW, Fraumeni JF Jr: Rising incidence of adenocarcinoma of the esophagus and gastric cardia. Jama 199|, 265(10): | 287-1289.

5. El-Serag HB, Mason AC, Petersen N, Key CR: Epidemiological differences between adenocarcinoma of the oesophagus and adenocarcinoma of the gastric cardia in the USA. Gut 2002, 50(3):368-372.

6. Wynder EL, Bross IJ: A study of etiological factors in cancer of the esophagus. Cancer 196I, 14:389-4I3.

7. Chen ZM, Xu Z, Collins R, Li WX, Peto R: Early health effects of the emerging tobacco epidemic in China. A I 6-year prospective study. Jama 1997, 278( I 8): I500-1504.

8. Thun MJ, Peto R, Lopez AD, Monaco JH, Henley SJ, Heath CW Jr, Doll $\mathrm{R}$ : Alcohol consumption and mortality among middle-aged and elderly U.S. adults. N Engl J Med 1997, 337(24): I705-1714.

9. Lee CH, Lee JM, Wu DC, Goan YG, Chou SH, Wu IC, Kao EL, Chan TF, Huang MC, Chen PS, Lee CY, Huang CT, Huang HL, Hu CY, Hung $\mathrm{YH}$, Wu MT: Carcinogenetic impact of ADH IB and ALDH2 genes on squamous cell carcinoma risk of the esophagus with regard to the consumption of alcohol, tobacco and betel quid. Int J Cancer 2008, I 22(6): | 347-I356.

10. Wu MT, Lee YC, Chen CJ, Yang PW, Lee CJ, Wu DC, Hsu HK, Ho CK, Kao EL, Lee JM: Risk of betel chewing for oesophageal cancer in Taiwan. Br J Cancer 200I, 85(5):658-660.

II. Lee CH, Lee JM, Wu DC, Hsu HK, Kao EL, Huang HL, Wang TN, Huang MC, Wu MT: Independent and combined effects of alcohol intake, tobacco smoking and betel quid chewing on the 
risk of esophageal cancer in Taiwan. Int J Cancer 2005, I I 3(3):475-482.

12. Zhi H, Zhang J, Hu G, Lu J, Wang X, Zhou C, Wu M, Liu Z: The deregulation of arachidonic acid metabolism-related genes in human esophageal squamous cell carcinoma. Int J Cancer 2003, 106(3):327-333.

13. Shamma A, Yamamoto H, Doki Y, Okami J, Kondo M, Fujiwara Y, Yano M, Inoue M, Matsuura N, Shiozaki H, Monden M: Up-regulation of cyclooxygenase-2 in squamous carcinogenesis of the esophagus. Clin Cancer Res 2000, 6(4): 1229- 1238.

14. Zimmermann KC, Sarbia M, Weber AA, Borchard F, Gabbert HE, Schror K: Cyclooxygenase-2 expression in human esophageal carcinoma. Cancer Res 1999, 59(1): 198-204.

15. Williams CS, Mann M, DuBois RN: The role of cyclooxygenases in inflammation, cancer, and development. Oncogene 1999 , I 8(55):7908-79|6.

16. Trifan OC, Hla T: Cyclooxygenase-2 modulates cellular growth and promotes tumorigenesis. J Cell Mol Med 2003, 7(3):207-222.

17. Tsujii M, DuBois RN: Alterations in cellular adhesion and apoptosis in epithelial cells overexpressing prostaglandin endoperoxide synthase 2. Cell 1995, 83(3):493-50I.

18. Tsujii M, Kawano S, Tsuji S, Sawaoka H, Hori M, DuBois RN: Cyclooxygenase regulates angiogenesis induced by colon cancer cells. Cell 1998, 93(5):705-716.

19. Nozoe T, Ezaki T, Kabashima A, Baba H, Maehara Y: Significance of immunohistochemical expression of cyclooxygenase-2 in squamous cell carcinoma of the esophagus. Am J Surg 2005, I89(I): II0-II5

20. Zhang X, Miao X, Tan W, Ning B, Liu Z, Hong Y, Song W, Guo Y, Shen Y, Qiang B, Kadlubar FF, Lin D: Identification of functional genetic variants in cyclooxygenase-2 and their association with risk of esophageal cancer. Gastroenterology 2005, I 29(2):565-576.

21. Ramsay RG, Friend A, Vizantios Y, Freeman R, Sicurella C, Hammett F, Armes J, Venter D: Cyclooxygenase-2, a colorectal cancer nonsteroidal anti-inflammatory drug target, is regulated by c-MYB. Cancer Res 2000, 60(7):|805-1809.

22. Ye W, Held M, Lagergren J, Engstrand L, Blot WJ, McLaughlin JK, Nyren O: Helicobacter pylori infection and gastric atrophy: risk of adenocarcinoma and squamous-cell carcinoma of the esophagus and adenocarcinoma of the gastric cardia. J Nat Cancer Inst 2004, 96(5):388-396.

23. Bahmanyar S, Zendehdel K, Nyren O, Ye W: Risk of oesophageal cancer by histology among patients hospitalised for gastroduodenal ulcers. Gut 2007, 56(4):464-468.

24. Henrik Siman J, Forsgren A, Berglund G, Floren CH: Helicobacter pylori infection is associated with a decreased risk of developing oesophageal neoplasms. Helicobacter 200I, 6(4):3I0-3I6

25. Wu DC, Wu IC, Lee JM, Hsu HK, Kao EL, Chou SH, Wu MT: Helicobacter pylori infection: a protective factor for esophageal squamous cell carcinoma in a Taiwanese population. Am J Gastroenterol 2005, 100(3):588-593.

26. Correa P: Human gastric carcinogenesis: a multistep and multifactorial process-First American Cancer Society Award Lecture on Cancer Epidemiology and Prevention. Cancer Res 1992, 52(24):6735-6740.

27. Ristimaki A, Honkanen $N$, Jankala $H$, Sipponen $P$, Harkonen $M$ : Expression of cyclooxygenase-2 in human gastric carcinoma. Cancer Res 1997, 57(7): 1276-1280.

28. Arakawa T, Higuchi K, Fukuda T, Fujiwara Y, Kobayashi K, Kuroki T: Prostaglandins in the stomach: an update. J Clin Gastroenterol 1998, 27(SuppI I):SI-II.

29. McCarthy CJ, Crofford LJ, Greenson J, Scheiman JM: Cyclooxygenase-2 expression in gastric antral mucosa before and after eradication of Helicobacter pylori infection. Am J Gastroenterol 1999, 94(5): $1218-1223$.

30. Zarrilli R, Tuccillo C, Santangelo M, Nardone G, Romano M Increased COX-2, but not COX-I, mRNA expression in Helicobacter pylori gastritis. Am J Gastroenterol 1999, 94(I I):3376-3378.

31. Konturek PC, Hartwich A, Zuchowicz M, Labza H, Pierzchalski P, Karczewska E, Bielanski W, Hahn EG, Konturek SJ: Helicobacter pylori, gastrin and cyclooxygenases in gastric cancer. J Physiol Pharmacol 2000, 5 I(4 Pt I):737-749.
32. Rosenberg JC, Franklin R, Steiger Z: Squamous cell carcinoma of the thoracic esophagus: an interdisciplinary approach. Curr Probl Cancer 198I, 5(I I): I-52.

33. Hosmer DWLS: Applied logistic regressioned. New York: John Wiley \& Sons; 2000.

34. Lee CH, Wu DC, Lee JM, Wu IC, Goan YG, Kao EL, Huang HL, Chan TF, Chou SH, Chou YP, Ho CK, Wu MT: Anatomical subsite discrepancy in relation to the impact of the consumption of alcohol, tobacco and betel quid on esophageal cancer. Int J Cancer 2007, I 20(8): 1755-1762.

35. Stata/SE I0, 2007. Statacorp LP. College station, TX. USA.

36. Kawabe A, Shimada Y, Uchida S, Maeda M, Sato F, Itami A, Imamura $M$ : Expression of cyclooxygenase- 2 is associated with carcinogenesis of the lower part of thoracic esophageal squamous cell carcinoma and p53 expression. Oncology 2002, 62(I):46-54

37. Sivula A, Buskens C], van Rees BP, Haglund C, Offerhaus G], van Lanschot |l, Ristimaki A: Prognostic role of cyclooxygenase-2 in neoadjuvant-treated patients with squamous cell carcinoma of the esophagus. Int J Cancer 2005, I I6(6):903-908.

38. Wu KL, Liou SH, Lay CS: Drug-induced gastropathy in elderly Taiwanese. Hepatogastroenterology 2000, 47(32):596-600.

39. Fu S, Ramanujam KS, Wong A, Fantry GT, Drachenberg CB, James SP, Meltzer SJ, Wilson KT: Increased expression and cellular localization of inducible nitric oxide synthase and cyclooxygenase 2 in Helicobacter pylori gastritis. Gastroenterology 1999, I I 6(6): |319-1329.

40. Toyoda M, Shirasaka D, Aoyama N, Watanabe Y, Miki I, Morita Y, Matsumoto Y, Mitani T, Miyachi H, Tamura T, Kasuga M: Helicobacter pylori eradication therapy on histologic change in the distal esophagus. Helicobacter 2006, I I (4):217-223.

41. Katelaris PH, Seow F, Lin BP, Napoli J, Ngu MC, Jones DB: Effect of age, Helicobacter pylori infection, and gastritis with atrophy on serum gastrin and gastric acid secretion in healthy men. Gut 1993, 34(8): 1032-1037.

42. El-Omar EM, Oien K, El-Nujumi A, Gillen D, Wirz A, Dahill S, Williams C, Ardill JE, McColl KE: Helicobacter pylori infection and chronic gastric acid hyposecretion. Gastroenterology 1997 I I3(1):15-24

43. Haruma K, Mihara M, Okamoto E, Kusunoki H, Hananoki M, Tanaka S, Yoshihara M, Sumii K, Kajiyama G: Eradication of Helicobacter pylori increases gastric acidity in patients with atrophic gastritis of the corpus-evaluation of 24-h pH monitoring. Aliment Pharmacol Ther 1999, I3(2): 155-162.

44. Gutierrez O, Melo M, Segura AM, Angel A, Genta RM, Graham DY: Cure of Helicobacter pylori infection improves gastric acid secretion in patients with corpus gastritis. Scand J Gastroenterol 1997, 32(7):664-668

45. Ohkuma K, Okada M, Murayama H, Seo M, Maeda K, Kanda M, Okabe $\mathrm{N}$ : Association of Helicobacter pylori infection with atrophic gastritis and intestinal metaplasia. J Gastroenterol Hepatol 2000 , 15(I0): I 05-IIII

46. Lurje G, Vallbohmer D, Collet PH, Xi H, Baldus SE, Brabender J, Metzger R, Heitmann M, Neiss S, Drebber U, Holscher AH, Schneider PM: COX-2 mRNA expression is significantly increased in acid-exposed compared to nonexposed squamous epithelium in gastroesophageal reflux disease. J Gastrointest Surg 2007, I I(9): I I05-IIII I.

47. Vallbohmer D, DeMeester SR, Oh DS, Banki F, Kuramochi H, Shimizu D, Hagen JA, Danenberg KD, Danenberg PV, Chandrasoma PT, Peters $\mathrm{JH}$, DeMeester TR: Antireflux surgery normalizes cyclooxygenase-2 expression in squamous epithelium of the distal esophagus. Am / Gastroenterol 2006, I0 I(7): I 458- 466.

48. Wu MT, Wu DC, Hsu HK, Kao EL, Lee JM: Relationship between site of oesophageal cancer and areca chewing and smoking in Taiwan. Br J Cancer 2003, 89(7): I 202-I204.

\section{Pre-publication history}

The pre-publication history for this paper can be accessed here:

\section{http://www.biomedcentral.com/1471-230X/9/37/pre} pub 